\title{
Developing Millennial's Spiritual Quotient In Gereja Penyebaran Injil, Medan
}

\author{
Yehuda \\ \{sembiringyehuda@gmail.com\} \\ Postgraduate Program, Pelita Kebenaran School of Theology
}

\begin{abstract}
Technological advances have both positive and negative impact on users, with the negative impact being accessing pornographic videos, causing people to become less able to associate or socializing. On the other hand, the positive impact can very quickly and easily access information. The researcher conducted research in the Gereja Penyebaran Injil Medan, against the millennials, namely teenagers in the Gereja Penyebaran Injil Medan. The result is that teenagers have very low spiritual quotient and this situation requires actions that will change mindset, attitudes.
\end{abstract}

Keywords: spiritual intelligence, millennials, youth.

\section{Introduction}

The rapid development of technology has brought a lot of difference, in particular pertaining the convenience in accessing information compared to the past. Information obtained, content that is in cyberspace, in one hand can be accessed by anyone in the present. Therefore millennials are very vulnerable to being influenced by many negative things. What researchers see in millennials in this day and age is the impact on spiritual intelligence, where spiritual quotient is an act, behavior, and mindset that is based on the Divine. As for things that are in spiritual intelligence, namely: conscience, conformity to situations and conditions/changing times, confidence, and sources of motivation. This is what raises questions for researchers, how is spiritual quotient in the Gereja Penyebaran Injil Medan who are in the category of millennials.

\section{Theoretical review}

Spiritual quotient is intelligence to deal with and solve problems of meaning or value, namely intelligence to position life behavior in the context of broader and richer meanings and intelligence to judge whetehr one's actions or way of life is meaningful compared to others (Marshal, 2000: 3 ) Spiritual quotient (SQ) can facilitate dialogue between mind and emotion, between soul and body. Also according to Marshal, spiritual quotient can also help someone to be able to carry out self-transcendence (Berman, 2001: 98).

Based on the views discussed above, spiritual quotient is a way of living according to the truth of God's Word and spiritual fellowship a life. Furthermore, there are four important things contained in spiritual quotient, namely conscience, adjustment to situations and conditions / changing times, confidence (confidence), and sources of motivation. 


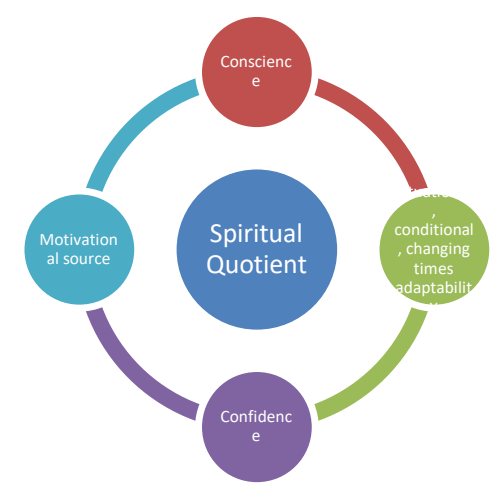

Fig. 1. Elements of spiritual quotient

Our awareness of good and evil is connected to our own actions (Andrew Wommack, 2018). Awareness is our conscience of the divine principles in holy life. Conscience in this case is where the individual can maintain holiness to not violate rules that are determined according to his beliefs. The emphasis of the researchers in this topic is the millennials who watched pornographic films. The technological developments have made possible information reception and internet access to become easy to use. It is therefore likely that millennials can easily access pornographic films. What is effect of watching porn? The impact received by the individual is that there is no more clarity of heart. This is what the focus of the researcher.

Adapting to situations and conditions and changing times is apparent clearly seen. Selfadjustment is a process that includes mental and behavioral responses in which individuals attempt to be able to successfully overcome the inner needs, tensions, conflicts, and frustrations that they experienced in order that a degree of harmony between demands from within themselves is realized with the expectations of the environment in which he lives (Desmita, 2009). Every time new things emerge, one example is the printed Bible was still in a book model while now many millennials use electronic Bibles, then sometimes there are some millennials when worship takes place using live streaming or selfie with cellphones. This is what shows the changing conditions of the times need restrictions or use at the right time. Masngudin and Santoso show that there are many teenagers who fail to make adjustments (Japar, 2014). Failure in adapting adolescents can be influenced by various factors, including low spiritual knowledge.

The next element is confidence which rises out of internet use which the researcher suspect that millennials in the present prefer to isolate themselves. As a result, these individuals will not be able to to socialize and socialize. When they have to meet other people, they do not have self-confidence. Therefore changes are needed in the individual or more precisely the individual's desire to change. Self-confidence is an aspect of personality that is important in the period of teenager development (Walgito, 2000). Self-confidence is one of the main capitals for success in life with optimism and the key to a successful and happy life (Leman, 2000; Taylor, 2009). The last element is the source of motivation. Because technology makes individuals spend more time with their gadgets, they have no motivation. This is certainly a crucial matter to consider because without motivation, individuals will lose their enthusiasm for life. Due to lack of maximizing time, the individual will lose the motivation that he needs. According to Mathis and Jackson (2006: 114) motivation is a desire in an individual that drives him to take act.

\section{Results}


The research was conducted in the Gereja Penyebaran Injil Medan, where the number of adolescents was 40 people, totaling 24 men and 16 women. After doing the research, the total number of interests of male adolescents with negative behavior was found to be $34 \%$ and positive behaviors as much as $66 \%$ and from the interests of adolescent girls who behaved negatively by $34 \%$ and positive behaviors by $66 \%$.



Fig. 2. Positive and negative among men

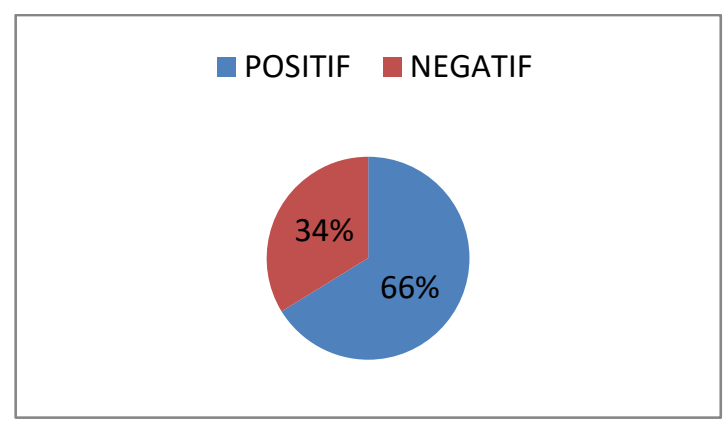

Fig. 3. Positive and negative among women

\section{Conclusion}

Based on the research questions formulated previously by the researcher, 'how are the spiritual quotient in the Gereja Penyebaran Injil Medan classified as millennial?' According to the results, it was found that there were $66 \%$ men with low spiritual quotient and $66 \%$ of women with low spiritual quotient out of the maximum value of $100 \%$. The total number of adolescents were 40 people, consisting of 24 men 16 women. From the results, the researcher concluded that the adolescent of the Gereja Penyebaran Injil Medan had low spiritual intelligence. It is recommended for the youth coordinator to give sermons containing warnings for teenagers to limit themselves from the rapid development of technology. Second, sermons must give teaching that is educational, containing doctrines that bind every teenager to control themselves. Seminars need to be held on the topic of good and proper technology usage according to the Word of God.

\section{Reference}


[1] Andrew Wommack (2018). Siapa yang Memberitahu Anda Bahwa Anda Telanjang? : Light Publishing

[2]Berman M. Devoloping SQ spiritual intellegence throught ELT, http://www.eltnesletter.12 juni 2001.

[3] Desmita. (2009). Psikologi Perkembangan. Bandung : Remaja Rosda Karya.

[4]Japar, M. (2014). Religiousity, Spirituality and Adolescents Self-Adjustment. International Education Studies, 7(10): 66.

[5]Leman, M. (2000). Membangun Rasa Percaya Diri Anak. Jakarta: Majalah Anakku.

[6]Mathis L. Robert dan John Jackson. 2006. Human Resource Management. Jakarta : Salemba Empat

[7]Taylor,R. (2009). Worklife, Mengembangkan Kepercayaan Diri. Jakarta: Erlangga.

[8]Walgito,B. (2000). Bimbingan dan Konseling (Studi dan Karir). Yogyakarta: Andi.

[9]Zohar, D Marshal I.Spiritual Intelligence The Ultimate Intelligence, Great Britain: Bloomsbury, 2000. 